\section{A critical appraisal of the harm reduction argument for heat-not- burn tobacco products}

\author{
Francisco J.R. Paumgartten ${ }^{1}$
}

Suggested citation Paumgartten FJR. A critical appraisal of the harm reduction argument for heat-not-burn tobacco products. Rev Panam Salud Publica. 2018;42:e161. https://doi. org/10.26633/RPSP.2018.161

\begin{abstract}
Heat-not-burn products (HNBs) are efficient nicotine delivery devices that heat tobacco instead of burning it, as conventional cigarettes do. Since heating yields less carbon monoxide and other tobacco pyrolysis-derived toxicants, tobacco companies claim that HNBs are less harmful than conventional cigarettes are. Although this hypothesis is plausible, no long-term clinical trials and/or observational studies are available to corroborate it. To overcome barriers to the entry of tobacco products to the market, manufacturers of HNBs argue that they are a new wave of harm reduction alternatives. Nonetheless, even if HNBs were in fact less harmful than conventional cigarettes, they would still have the potential to cause nicotine addiction (a major health hazard) and other harms to smokers' health. HNBs deliver nicotine, provide users a tobacco aroma and flavor and some rituals of smoking, and are supposedly safer than conventional cigarettes. Owing to these features, HNBs are likely to enhance smoking appeal and initiation among young persons and discourage smokers' attempts to quit. In other words, if HNBs were freely available on the market, they would increase the prevalence of smoking. However, HNBs may constitute a harm reduction alternative for nicotinedependent smokers who are unable or unwilling to quit smoking. Given these facts, approval of HNBs for use under medical supervision (prescription only), along with strict restrictions on advertising, is a balanced regulatory option
\end{abstract}

\footnotetext{
The National School of Public Health, Oswaldo Cruz Foundation (FIOCRUZ), Rio de Janeiro, Rio de Janeiro, Brazil. Send correspondence to Francisco J.R. Paumgartten, paum@ensp.fiocruz.br
}

that would reconcile the therapeutic needs of nicotineaddicted patients with the public heath goal of achieving a smoke-free generation in the near future.

Keywords Tobacco use disorder; neoplasms; harm reduction; nicotine; smoking.

Nicotine is a psychoactive alkaloid with stimulant properties and a high additive potential when exposure occurs by inhalation. Owing to these features and a high concentration in tobacco leaves, nicotine plays a pivotal role in the smoking habit. Actually, cigarettes are efficient nicotine delivery devices designed to be attractive to new users and to make them habitual smokers. A recent meta-analysis of representative surveys indicated that over two-thirds of people who try one cigarette become daily smokers at least for a period of time (1). It is of note that a considerable proportion of those who became daily smokers continue to smoke despite concerns about health harms and a desire to quit.

Like the dependence on illegal drugs and alcohol, nicotine addiction is a chronic and relapsing illness resistant to treatment. A longitudinal cohort study of a large number of smokers suggested that a current smoker tries to quit on average 30 times or more before successfully stopping smoking for one year or longer (2). Another study estimated that among people who have been abstinent for 12 months, 37.1\% of them will relapse within 10 years (3). Given the foregoing facts, prevention of smoking initiation among young persons is paramount for a long-term reduction in the incidence of cancers of the lung, larynx, and several other sites; chronic obstructive pulmonary disease (COPD); cardiovascular deaths; and a variety of other tobacco-related medical conditions.

Notwithstanding the many obstacles still ahead on this road, prevention of tobacco-related chronic diseases is certainly one of the past five decades' top public health achievements. A sharp decrease in smoking prevalence in recent decades has resulted from the introduction of various strict tobacco control policies, including a ban on tobacco product advertising, a prohibition on smoking in closed public spaces, mass-media antismoking campaigns, raising taxes on cigarettes, and the creation of smoking cessation programs (4). In Brazil, data from the National Cancer Institute demonstrated that smoking rates among adults (men and women aged 18 and over) declined 
steadily, from $34.8 \%$ in 1989 to $22.4 \%$ in $2003,18.5 \%$ in 2008 , and $14.7 \%$ in 2013 (5). It was estimated that 420000 smoking-attributable deaths were prevented up to 2010 and that around 7 million premature deaths will be averted by 2050 (6). Tobacco control policies implemented in the United States of America and other countries accomplished similar results in the prevention of tobacco-related diseases. Smoking rates among adults in the United States, for instance, dropped from $42.4 \%$ in 1965 to $25.5 \%$ in 1990 , and to $15.1 \%$ in 2015 $(7,8)$. The incidence of lung cancer in the United States also steadily declined, by $2.5 \%$ per year in males from 2005 to 2014 , and by $1.2 \%$ per year in females from 2002 to 2015 (9). This fall in disease rates is consistent with the fact that tobacco smoking is a major risk factor for malignant respiratory tract tumors.

The implementation of effective tobacco control policies led to the cigarette market shrinking, thereby threatening the future of the tobacco business. Unsurprisingly, tobacco companies are fiercely opposed to any additional control measures, such as banning the use of additives in tobacco products and making standardized plain packaging for cigarettes mandatory (4). Recently, tobacco companies bet on heat-not-burn products (HNBs) to keep their business afloat for as long as possible. Unlike conventional cigarettes that burn tobacco (at $600^{\circ} \mathrm{C}$ ), HNBs heat it $\left(\right.$ at $\left.300^{\circ} \mathrm{C}\right)$, yielding a vapor that contains nicotine aerosols.

Heat-not-burn tobacco devices deliver efficiently aerosolized nicotine via the lungs to the blood stream and brain, and they retain a tobacco aroma and flavor and some of the rituals of smoking. HNBs also massively reduce the levels of carbon monoxide (CO), tar, and carcinogenic compounds found in the smoke of conventional cigarettes. A comparative analysis showed that while concentrations of nicotine are similar, levels of $\mathrm{CO}$ and of tobacco-specific nitrosamines (TSNAs) in the vapor of HNBs (e.g., iQOS from Philip Morris International (PMI) Inc.) are, respectively, .01 and .20 times the concentrations found in the mainstream smoke of conventional (combustion) cigarettes (10). Nonetheless, a recent study found that HNBs do char and that charring increases if the devices are not cleaned after heating the tobacco sticks. PMI recommends cleaning the HNB device after every 20 heat sticks, but it was found that charring builds up after every tobacco stick, an indication that some pyrolysis of tobacco constituents may occur at temperatures less than $350^{\circ} \mathrm{C}(11)$. Moreover, it was reported that melting of the polymer film filter $\left(\right.$ at $90^{\circ} \mathrm{C}$ ) releases formaldehyde cyanohydrin, a toxicant of concern (11).

The tobacco companies maintain that HNBs are safer than conventional cigarettes, and that smokers who are addicted to nicotine would greatly benefit by switching to HNBs. Moreover, they also argue that if HNBs were freely available on the market, there would be a decrease in the consumption of conventional cigarettes, leading to a decline in the incidence of tobacco-related illnesses and deaths in the population. A note posted on the PMI Science website illustrates the industry discourse and arguments to convince regulators and the public that HNBs and electronic cigarettes are a "new wave" of alternative harm reduction products. According to the PMI website, "tobacco harm reduction at the individual and population level, achieved by providing less risky alternative nicotine delivery products, is an important public health strategy, complementary to prevention and cessation efforts" (12). That website also says that to benefit public health, three conditions need to be met: 1) smokers must find these products satisfying as alternatives to smoking conventional cigarettes; 2) an actual reduction in risk promised by alternative products must be scientifically substantiated; and 3) the benefits and risks of these products, including those associated with initiation and cessation, must be assessed to determine their overall net impact on public health (12). The website implicitly suggests that PMI developed HNBs that would fulfill these three requirements.

A recent study estimated that the consumption of HNBs is poised for explosive growth in coming years (13). In an unprecedented marketing campaign, PMI (which is one of the biggest tobacco companies) announced that it wants to stop selling conventional cigarettes in the United Kingdom and to focus on alternative nicotine delivery products that are supposedly less harmful to health.

In Brazil, where the National Sanitary Surveillance Agency (ANVISA) has not granted marketing authorization for electronic nicotine delivery products, tobacco companies are engaged in a fierce lobbying campaign for that approval, based on harm reduction arguments.

The health risks posed by nicotine and the overall net impact of alternative nicotine delivery products on public health are key questions in this controversial issue.

This objective of this opinion article is to analyze the industry's harm reduction argument and the possible public health consequences of approving HNBs for marketing in Brazil and elsewhere.

\section{HARMFULNESS OF NICOTINE}

The industry discourse on harm reduction tends to minimize the role of nicotine in tobacco-related illnesses. Nicotine addiction per se, however, is a major health hazard. Available data suggest that nicotine is an important player in cardiovascular diseases associated with smoking. Although $\mathrm{CO}$ and other tobacco smoke toxicants are likely to be involved in cardiovascular morbidity, it is plausible to think that long-term exposure to nicotine adds to acute cardiovascular events, particularly in smokers with underlying coronary heart disease (14).

Several authors believe that nicotine accelerates the formation of atheromatous plaques in the artery walls (14). A historical cohort study indicated that during 52 weeks of follow-up there were more cardiovascular events among patients who were prescribed nicotine replacement therapy (NRT) (such as nicotine gum and 
patches) than there were among smokers receiving smoking cessation advice alone (15). However, another, more recent study found no evidence that NRT increases the risk of cardiovascular events during or after smoking cessation treatment (16). At any rate, nicotine increases the heart rate and blood pressure in non-tobacco smokers, and a clinical study showed that nicotine administered in a chewing gum had a direct (moderate) vasoconstrictor effect in the nonischemic human heart (17). While the comparative effects of conventional cigarettes and alternative nicotine delivery products on cardiovascular morbidity remain largely unstudied, the available evidence suggests that nicotine, from whatever nicotine delivery product, has detrimental effects on the cardiovascular system.

\section{HARM REDUCTION AT INDIVIDUAL AND POPULATION LEVELS}

Another key issue in this debate is the extent to which a harm reduction approach for a group of smokers addicted to nicotine would translate into a public health benefit at a population level.

Bekki et al. (10) indicated that levels of toxicants in the vapor of the PMI $i Q O S$ heat-not-burn tobacco product are lower than the levels in the smoke of conventional cigarettes. Since lung cancer, COPD, and other chronic diseases are associated with exposure to smoke toxicants, the industry argues that the risk of tobacco-related illnesses decreases when the smoker switches from conventional cigarettes to alternative nicotine delivery products. While this hypothesis remains plausible, it lacks corroboration by evidence from long-term clinical trials and/or observational studies. Furthermore, smoking cessation is the best way to prevent or reduce the risk of tobacco-attributable diseases, and thus it should be the primary goal of any therapeutic intervention. Concerns about health harms push smokers to attempt to quit, with or without medical support and the help of NRTs. Some of those smokers achieve abstinence after some failed quit attempts. Since HNBs are supposedly healthier than conventional cigarettes, health-conscious smokers might prefer switching from combustion cigarettes to this alternative nicotine delivery product instead of attempting to achieve smoking abstinence. At any rate, HNBs might constitute a harm-reduction alternative for nicotine-addicted smokers who are unable to quit (i.e., who failed repeated quit attempts with NRT) or are unwilling to quit smoking.

The unrestricted availability of HNBs on the market, however, will not necessarily result in a long-term health benefit at a population level. Since it is claimed that HNBs are safer than conventional cigarettes, one could expect an enhancement of smoking appeal and initiation among young persons and a deterrence to quit attempts among habitual smokers. That is, if HNBs eventually break into the market, the prevalence of smoking in the general population is likely to increase, and thus a greater number of people would be exposed to nicotine and other chemicals found in the tobacco vapor. Moreover, as demonstrated for electronic cigarettes (ECs), heat-not-burn tobacco products may act as a gateway to conventional cigarette smoking. A Korean cross-sectional study by Lee et al. (18) showed that the use of ECs was associated with increased cigarette smoking in youth, and that a dual use of ECs and conventional cigarettes was the dominant pattern among adolescents and adults. Similarly, a study conducted in the United States suggested that the use of ECs encourages conventional cigarette use among adolescents (19). ECs heat a liquid that contains nicotine, flavors, propylene glycol, and/or glycerin. In contrast, HNBs are nicotine delivery products that provide users with a typical tobacco flavor, and so HNBs generally find full acceptance among conventional cigarette smokers. It is therefore reasonable to think that the dual use of HNBs and conventional cigarettes by young persons and adults may also occur, and could be even more frequent than that of ECs and conventional cigarettes.

It is noteworthy that the foreseeable adverse effects that alternative nicotine delivery devices have on the prevalence of smoking contrast with the good results achieved by the effective tobacco control policies adopted in recent decades. As mentioned earlier, tobacco control policies led to consistent declines in the rates of smoking and tobacco-related diseases and deaths. Additional measures, such as a ban on tobacco additives and a mandatory plain standardized cigarette package, could reduce even more the smoking prevalence and the incidence of tobacco-attributable morbidity and mortality.

In summary, HNBs are likely to expand the tobacco market by attracting young people and reducing smoking cessation rates. Obviously, from a public health perspective, this would be a frustrating and premature end to a so-far successful journey towards the first smoke-free generation.

\section{HEAT-NOT-BURN TOBACCO AND ELECTRONIC CIGARETTES}

HNB cigarettes broke into the market in Japan in 2014, while ECs appeared in the mid-2000s. There are, therefore, more studies on the potential health effects of ECs. Since they may cause irritation of the mouth and throat and do not mimic tobacco cigarette's taste and favor, as HNBs do, ECs do not satisfy many smokers. It has been claimed that ECs are safer than conventional cigarettes and can be used in efforts to quit smoking. This assertion, however, remains unsubstantiated by robust research. A systematic review (20) of randomized controlled trials (RCTs) found two RCTs suggesting that ECs were more effective than placebo in helping smokers to quit smoking, and one trial showing no difference between ECs and NRT nicotine patches in smoking cessation therapies. The authors' confidence in the review's conclusions, however, was rated as low by the Grading of Recommendations, Assessment, Development and Evaluation (GRADE) standards because of the small 
number of trials, low event rates, and wide confidence intervals around the estimates mean (20). (GRADE is a systematic approach to rating the quality of the evidence in systematic reviews and other evidence syntheses, as well as the strength of the recommendation (21)). A review of ECs (22) highlighted that while these products release lower levels of smoke carcinogens than combustion cigarettes do, they still yield ultrafine particles, acrolein (from propylene glycol and glycerin), highly oxidant free radicals, and other toxicants that raise concerns regarding cardiovascular and non-cancer diseases. The use of ECs as a harm reduction approach among smokers at risk of or with COPD lacks support from long-term studies. Similarly, a prospective cohort study revealed that ECs were associated with worse pulmonary-related health outcomes, but not with smoking cessation (23). In summary, allegations about the long-term safety of ECs are, at best, questionable. Further, it is unclear whether ECs are effective and, if so, whether they are more effective and safer than nicotine patches for smoking cessation interventions.

\section{CONCLUSIONS}

Some of the industry arguments for the health benefits of alternative nicotine delivery products may be valid, while others are misleading. Even if HNBs were in fact less harmful than conventional cigarettes, they would still have the potential to cause nicotine dependence and other adverse effects such as damaging the cardiovascular system and the unborn child. The tobacco industry claims that HNBs are safer than conventional cigarettes, but long-term RCTs and/or observational studies are lacking to corroborate this assertion. It is plausible to think that alternative nicotine delivery products such as ECs and HNBs enhance smoking appeal and initiation among young persons. Moreover, HNBs are also likely to discourage quit attempts. It is reasonable to expect that if HNBs and ECs break into the market they will increase the prevalence of smoking. Owing to this possibility and health risks posed by nicotine and other vapor constituents, HNBs should not be made freely available on the market. HNBs, however, might be a harm reduction approach for a group of smokers who are unable to quit or are unwilling to do so. The sale of HNBs for use under medical supervision (prescription only), with strict restrictions on product advertising, is a balanced regulatory alternative that would reconcile the harm reduction needs of nicotine-addicted patients with the collective health goal of achieving the first smoking-free generation in the near future.

Acknowledgments. The author is grateful to Prof. Dr. Ana Cecilia A.X. de Oliveira, from the National School of Public Health - FIOCRUZ, for her valuable suggestions on improving the manuscript.

Funding. The author's research work was supported by grants from Brazil's National Council for Scientific and Technological Development (CNPq) and the Carlos Chagas Filho Foundation for Research Support of the State of Rio de Janeiro (FAPERJ).

Conflict of interests. The author declares no conflict of interests. He has received no honorarium, reimbursement for lectures, research grants, or other financial support of any kind from tobacco companies.

Disclaimer. The author holds sole responsibility for the views expressed in the manuscript, which may not necessarily reflect the opinion or policy of the RPSP/ $\mathrm{PAJPH}$ or PAHO.

\section{REFERENCES}

1. Birge M, Duffy S, Miler JA, Hajek P. What proportion of people who try one cigarette become daily smokers? A meta-analysis of representative surveys. Nicotine Tob Res. 2017 Nov 4. doi: 10.1093/ntr/ntx243. [Epub ahead of print].

2. Chaiton M, Diemert L, Cohen JE, Bondy SJ, Selby P, Philipneri A, et al. Estimating the number of quit attempts it takes to quit smoking successfully in a longitudinal cohort of smokers. BMJ Open. 2016;6(6):e011045. doi: 10.1136/ bmjopen-2016-011045.

3. Hawkins J, Hollingworth W, Campbell R. Long-term smoking relapse: a study using the British household panel survey. Nicotine Tob Res. 2010;12(12):1228-35. doi: $10.1093 / \mathrm{ntr} / \mathrm{ntq} 175$.

4. Ferreira CG, Silveira D, Hatsukami DK, Paumgartten FJ, Fong GT,
Glória MB, et al. The effect of tobacco additives on smoking initiation and maintenance. Cad Saude Publica. 2015;31(2):223-5.vdoi: 10.1590/0102-311XPE010215.

5. Instituto Nacional de Câncer Observatório da Política Nacional de Controle do Tabaco. Available from: http:/ / www2.inca.gov.br/ wps/wcm/connect/observatorio_ controle_tabaco/site/home/dados numeros/prevalencia-de-tabagismo Accessed on 10 January 2018.

6. Levy D, de Almeida LM, Szklo A. The Brazil SimSmoke policy simulation model: the effect of strong tobacco control policies on smoking prevalence and smoking-attributable deaths in a middle income nation. PLoS Med.2012;9(11):e1001336. doi: 10.1371/journal.pmed.1001336.

7. Centers for Disease Control and Prevention. Trends in cigarette smoking among high school students and adults, United States, 1965-2014. Available from: https://www.cdc. gov/tobacco/data_statistics/tables/ trends/cig_smoking/index.htm Accessed on 8 January 2018.

8. Centers for Disease Control and Prevention. Current cigarette smoking among adults in the United States. Available from: https: / / www. cdc.gov/tobacco/data_statistics / fact_sheets/adult_data / cig smoking/index.htm Accessed on 8 January 2018.

9. American Cancer Society. Facts \& figures 2018: rate of deaths from cancer continues decline. Cancer mortality drops another $1.7 \%$. Available from: https:/ / www.cancer. org/latest-news / facts-and-figures2018-rate-of-deaths-from-cancercontinues-decline.html Accessed on 4 January 2018. 
10. Bekki K, Inaba Y, Uchiyama S, Kunugita N. Comparison of chemicals in mainstream smoke in heatnot-burn tobacco and combustion cigarettes. J UOEH. 2017;39(3):201-7. doi: 10.7888/juoeh.39.201.

11. Davis B, Williams M, Talbot P. iQOS: evidence of pyrolysis and release of a toxicant from plastic. Tob Control. 2018 Mar 13. pii: tobaccocontrol-2017-054104. doi: 10.1136/tobaccocontrol-2017-054104. [Epub ahead of print].

12. Philip Morris International Science USA. The harm reduction opportunity. The role of nicotine. Available from: https://pmiscienceusa.com/anew-option-smokers/nicotine-andharm-reduction/ Accessed on 12 January 2018.

13. Caputi TL, Leas E, Dredze M, Cohen JE, Ayers JW. They're heating up: Internet search query trends reveal significant public interest in heat-notburn tobacco products. PLoS One. 2017;12(10):e0185735. doi: 10.1371/ journal.pone.0185735.

14. Benowitz NL, Burbank AD. Cardiovascular toxicity of nicotine: implications for electronic cigarette use. Trends Cardiovasc Med. 2016;26(6):515-23. doi:10.1016/j.tcm. 2016.03.001.
15. Dollerup J, Vestbo J, Murray-Thomas T, Kaplan A, Martin RJ, Pizzichini E, et al. Cardiovascular risks in smokers treated with nicotine replacement therapy: a historical cohort study. Clin Epidemiol. 2017;9:231-43. doi: 10.2147/CLEP.S127775.

16. Benowitz NL, Pipe A, West $R$, Hays JT, Tonstad S, McRae T, et al. Cardiovascular safety of varenicline, bupropion, and nicotine patch in smokers: a randomized clinical trial. JAMA Intern Med. 2018 May 1;178(5):622-31. doi: 10.1001/ jamainternmed.2018.0397.

17. Kaijser L, Berglund B. Effect of nicotine on coronary blood-flow in man. Clin Physiol. 1985;5(6):541-52.

18. Lee S, Grana RA, Glantz SA. Electronic cigarette use among Korean adolescents: a cross-sectional study of market penetration, dual use, and relationship to quit attempts and former smoking. J Adolesc Health. 2014;54(6):684-90. doi:10.1016/j.jadohealth.2013.11.003.

19. Dutra LM, Glantz SA. Electronic cigarettes and conventional cigarette use among U.S. adolescents: a cross-sectional study. JAMA Pediatr. 2014;168 (7):610-7.

20. Hartmann-Boyce J, McRobbie H, Bullen C, Begh R, Stead LF, Hajek P.
Electronic cigarettes for smoking cessation. Cochrane Database Syst Rev. 2016;9:CD010216.

21. Guyatt GH, Oxman AD, Kunz R, Falck-Ytter Y, Alonso-Coelho P, Schünemann $\mathrm{HJ}$, et al. GRADE: an emerging consensus on rating quality of evidence and strength of recommendations. BMJ. 2008;336: 924-6.

22. Glantz SA, Bareham DW. E-cigarettes: use, effects on smoking, risks, and policy implications. Annu Rev Public Health. 2018;39:215-35. doi: 10.1146/ annurev-publhealth-040617-013757.

23. Bowler RP, Hansel NN, Jacobson S, Graham Barr R, Make BJ, Han MK, et al. Electronic cigarette use in US adults at risk for or with COPD: analysis from two observational cohorts. J Gen Intern Med. 2017;32(12):1315-22. doi: 10.1007/ s11606-017-4150-7.

Manuscript received on 20 January 2018. Revised version accepted for publication on 6 July 2018.
RESUMEN

Evaluación crítica del argumento de que los productos que calientan el tabaco en vez de quemarlo son menos nocivos

\author{
Palabras clave
}

Los productos de tabaco calentado (PTC) son dispositivos eficientes para la administración de nicotina que calientan el tabaco en vez de quemarlo (como sucede con los cigarrillos convencionales). Al calentar el tabaco se produce menos monóxido de carbono y se liberan menos sustancias tóxicas derivadas de la pirólisis del tabaco; por tanto, las empresas tabacaleras sostienen que los PTC son menos nocivos que los cigarrillos convencionales. Aunque esta hipótesis es verosímil, no hay ningún ensayo clínico ni estudios de observación a largo plazo que la corroboren. Para superar las barreras a la entrada de los productos de tabaco en el mercado, los fabricantes de PTC sostienen que estos productos son una nueva ola de alternativas menos dañinas. Sin embargo, aunque los PTC fueran realmente menos nocivos que los cigarrillos convencionales, seguirían teniendo el potencial de causar adicción a la nicotina (un riesgo grave para la salud), así como otros perjuicios para la salud de los fumadores. Los PTC administran nicotina y brindan a los consumidores el aroma y el sabor del tabaco, así como algunos de los rituales del acto de fumar, a la vez que son supuestamente más seguros que los cigarrillos convencionales. Precisamente por estas características, los PTC pueden volverse una forma de fumar atractiva que incite a los jóvenes a comenzar a usarlos y disuada a los fumadores de dejar de hacerlo. Es decir, si los PTC estuviesen disponibles sin restricciones en el mercado, aumentaría la prevalencia del consumo de tabaco. Sin embargo, los PTC pueden ser una alternativa menos dañina para los fumadores adictos a la nicotina que no pueden o no quieren dejar de fumar. Por todo ello, aprobar los PTC para su uso bajo supervisión médica (únicamente con prescripción), junto con restricciones estrictas en cuanto a su promoción publicitaria, es una opción regulatoria en la que se equilibrarían las necesidades terapéuticas de los pacientes adictos a la nicotina con el objetivo de salud pública de conseguir una generación sin tabaco en un futuro próximo.

Tabaquismo; neoplasias; reducción del daño; nicotina; fumar. 
RESUMO Os cigarros aquecidos são aparelhos eficientes de liberação de nicotina que aquecem o tabaco em vez de queimá-lo como os cigarros convencionais.

Uma análise crítica do argumento de redução de danos dos cigarros aquecidos Como o aquecimento produz menos monóxido de carbono e outros produtos tóxicos derivados da queima do tabaco, as empresas de tabaco alegam que os cigarros aquecidos são menos prejudiciais que os convencionais. Apesar de esta hipótese ser plausível, não existem estudos clínicos e/ou observacionais de longo prazo para corroborá-la. Para vencer os obstáculos à entrada no mercado dos produtos derivados do tabaco, os fabricantes dos cigarros aquecidos argumentam que eles fazem parte de um novo ciclo de alternativas para redução de danos. No entanto, mesmo se os cigarros aquecidos forem de fato menos prejudiciais que os convencionais, eles continuam tendo o potencial de causar dependência da nicotina (um sério risco à saúde) e outros danos à saúde dos fumantes. Os cigarros aquecidos liberam nicotina, dispensando o aroma e o sabor do tabaco e proporcionando ao usuário alguns dos rituais do ato de fumar, e supostamente seriam mais seguros que os cigarros convencionais. Devido a essas características, eles podem tornar o ato de fumar mais atraente e fazer os jovens começarem a fumar e desincentivar os fumantes a parar de fumar. Em outras palavras, se forem comercializados livremente no mercado, aumentariam a prevalência do tabagismo. Porém, os cigarros aquecidos podem ser uma alternativa para a redução de danos em fumantes dependentes da nicotina que não conseguem ou relutam em parar de fumar. Diante destes fatos, a aprovação dos cigarros aquecidos para uso sob supervisão médica (com prescrição), aliada a restrições rigorosas à publicidade do produto, é uma opção regulamentar ponderada que conciliaria as necessidades terapêuticas dos pacientes dependentes de nicotina com a meta de saúde pública de ter uma geração que não fuma em um futuro próximo.

Palavras-chave Tabagismo; neoplasias; redução do dano; nicotina; fumar. 